\section{Ambisiøst og interessant om vold}

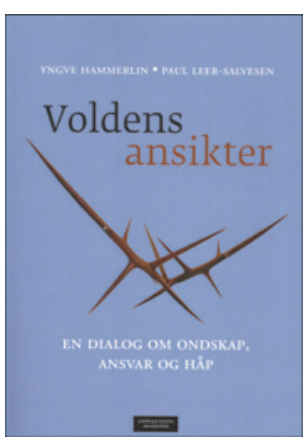

Yngve Hammerlin, Paul Leer-Salvesen Voldens ansikter

En dialog om ondskap, ansvar og håp. $266 \mathrm{~s}$ Oslo: Cappelen Damm Akademisk, 2014 NOK 399

ISBN 978-82-02-43197-6

Hammerlin og Leer-Salvesen går bredt til verks når de forsøker å behandle temaene vold, overgrep og radikal ondskap over 266 sider. De bruker sine erfaringer fra arbeid i fengselsvesenet, med innsatte og drapsmenn, og de har sin bakgrunn i filosofi, samfunnsvitenskap, etikk og teologi. Ikke minst har teksten også et personlig preg, idet vi får innblikk i Hammerlins oppvekst med en voldelig far. Han prøver å forstå sin fars motiver, tanker og følelser i forhold til den volden og de overgrepene familien ble utsatt for. Styrken er derfor det brede kunnskapstilfanget og nærheten til personlige erfaringer fra forskning, praksis og eget liv.

Boken er bygd opp som en dialog mellom de to forfatterne rundt 15 temaer som spenner fra grunnlagsfilosofiske betraktninger over det ondes problem, til voldens mange ansikter, gjennom temaer som selvmord og vold, estetikk og vold, kjønn og vold, samt kapitler der temaer som samvittighet, skyld og tilgivelse tas opp, for å nevne noen. Avslutningsvis er det noen interessante rettsfilosofiske betraktninger om 22 . juli-massakren.

Forfatterne har et positivt syn på mennesket og behandler temaer som overgrep og vold med en tro på håp, tilgivelse og soning. Likevel er de også spørrende til det radikalt onde, der volden har et slikt omfang at tilgivelse antakelig ikke er et valg, ikke en gang en mulighet. Dette ser vi ved omfattende folkemord og massemord. Her møter man også det gåtefulle i mennesket, når tilsynelatende vanlige mennesker kan begå ekstraordinære handlinger i voldens navn. Forfatteren berører dette spørsmålet, særlig i kapitlet om 22. juli-massakren, men diskuterer det ikke mer inngående.

At forfatterne prøver å fange alt, blir en svakhet. Boken preges av gjentakelser og stadig digresjoner og referanser til relevant litteratur. Man savner mer dypdykk i temaene som behandles, der noen temaer kunne vært valgt ut for mer inngående diskusjon og refleksjon. Med den personlige stilen der forfatterne tydelig kjenner og respekterer hverandre, blir det litt preg av skryt av den andre. Man kan nesten få inntrykk av at de skal vise omverdenen hvor mye de har lest og kan.

Når det er sagt, er bredden også en styrke. Den gir innblikk i mange og viktige temaer, den er personlig og nær og den er preget av to forfattere med stor tyngde og erfaringsvisdom. Boken kan anbefales.

\section{Per Nortvedt}

Professor, Senter for medisinsk etikk, Institutt for helse og samfunn Universitetet i Oslo

\section{Har vi noe å lære av en kriger?}

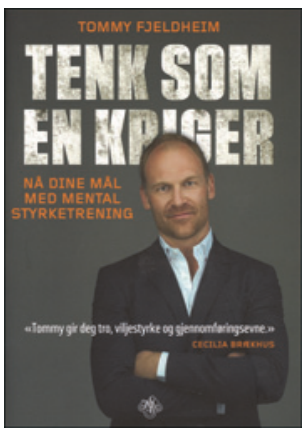

Tommy Fjeldheim

Tenk som en kriger

- Nå dine mål med mental styrketrening. 215 s, ill. Oslo: J.M. Stenersens forlag, 2014 Pris NOK 349 ISBN 978-82-72013-562-5

Har redaksjonen i Tidsskriftet tenkt at dette er en aktuell bok for oss helsearbeidere fordi det stadig kriges på våre arbeidsplasser? Uansett er det betimelige å spørre: Hva kan vi lære av en elitesoldat i Forsvarets spesialkommando?

Forfatteren formidler gode intensjoner på coveret når han sier: «Jeg vil at du skal finne krigeren i deg når du hører den indre stemmen som forteller deg at du ikke kan, ... at du ikke er god nok...ta opp kampen når du kjenner frykten for det ukjente...». Her er han i godt selskap med en som formet sine udødelige litterære mesterverk for ca. 150 år siden. Henrik Ibsen skrev i et dikt i 1878 følgende: «At leve er krig med trolde i hjertets og hjernens hvelv. At digte, det er at holde dommedag over seg selv».

Leser vi Fjeldheim som vi leser Ibsen, kan begges budskap tolkes som at den viktigste krigen vi fører ikke er å nedkjempe en fiende slik elitesoldaten trenes opp til. «Krigen» i våre liv foregår på vår egen indre arena, vi er selv vår vanskeligste motstander. Dessverre «drukner» dette perspektivet i bokens form og språkdrakt. Utsagn som: «Krigeren vil bruke den makt han er tildelt...vel vitende om at det til tider kan bli brutalt» (s. 11), «For meg handler mental råskap om å kjenne min identitet...» (s. 12) og «Jeg lever for meg selv, ikke for andre...» (s. 76) er ikke helt i tråd med holdninger vi tror fremmer samarbeid og godt klima i helseinstitusjoner. At anbefalingen fra den hardtslående bokseren Cecilia Brækhus troner på forsiden, svekker ikke det «krigerske» totalinntrykket.

Til tross for dette, forfatteren skal krediteres for mye selverfart kunnskap om å øke selvtillit og mestringsevne. Å holde ut påkjenninger som kan betegnes som på grensen til det umenneskelige, krever en knallhard innstilling og stayerevne. Slagord i Forsvarets spesialkommando som «Det er ingenting som er umulig. Det umulige tar bare litt lenger tid» og «Vi løser oppdraget, uavhengig av forutsetningene» (s. 105) viser at forfatteren er godt sosialisert inn i rollen som elitesoldat.

Andre formuleringer som: «Målet er alltid å få folk til å dra i samme retning. Det forutsetter at hver enkelt har et eierskap til målet der fremme» (s. 128) og sitat fra Churchill: «If you fail to plan, you are planning to fail» (s. 129) er gode råd til ledere i helseforetak der planlegging, konstruktiv dialog og diplomati bør ha forrang fremfor «krigerske» prinsipper.

Boken er inndelt i syv kapitler, den er lettlest og kan tjene som god sengelektyre for dem som liker å vite hvordan de «barskeste» av de «barske» har det i vårt samfunn. Men for undertegnede er det mer visdom å hente fra Ibsen enn fra Tommy Fjeldheim.

\section{Tore Gude}

Professor emeritus, Avdeling for atferdsfag

Universitetet i Oslo 